\title{
KONSEP DIRI SEORANG DA'I
}

\author{
Noormawanti \\ Universitas Muhamadiyah Metro \\ noormawanti13@gmail.com \\ Iswati \\ Universitas Muhamadiyah Metro \\ iswatiummetro@yahoo.com
}

\begin{abstract}
The concept of self is an understanding of the attitude of the individual towards himself, resulting in the interaction of two or more people. Selfconcept is a factor that communicates with others. The concept of self is the views and attitudes of individuals towards themselves, characteristics and individual and self-motivation. The self-view includes not only individual strengths but also weaknesses and even failures. This self-concept is psychological, social and physical. Selfconcept is our views and feelings about ourselves, which includes physical, psychological and social aspects. The concept of self is not just a descriptive picture, but also an assessment of ourselves, including what we think and how we feel. Anita Taylor defines self-concept as "all you think and feel about you, the entire complex of beliefs and attitudes you hold abaout yourself '. Human behavior is a product of their interpretation of the world around them through social interaction. Behavior is often a choice as a feasible thing to do based on how it defines the existing situation. The definition they give to other people, situations, objects and even themselves determines their behavior. So it is individuals who are considered active to regulate and determine their own behavior and environment. While the core of the individual is consciousness (consciousness). self-development depends on communication with others, which shape or influence themselves
\end{abstract}

Keywoard: Self Concept, $D a^{\prime} i$ 


\section{A. Pendahuluan}

Dakwah memiliki makna atau pengertian berdasarkan etimologi dan terminology. Dakwah secara etimologi berawal dari bentuk masdar dari kata yad'u (fi'il mutbari') dan da'a (fi'il madi) yang berarti memanggil (tucal), mengundang (to invite), mengajak (to summer), menyeru (to propo), mendorong (to urge), dan memohon (to pray). Sedangkan pengertian dakwah secara termininologi yaitu menurut Syah Alimahfud adalah dakwah merupakan kegiatan mendorong akan terus memberikan motivasi agar selaluu melakukan kebajikan dan mengikuti petunjuk, yang slalu memperintahkan untuk berbuat makruf dan mencegah dan yang mungkar agar mereka itu dapat kebahagiaandunia akhirat. ${ }^{1}$

Kata Da'i berasal dari bahasa arab bentuk mudzkar yang berarti orang yang mengajak. Sedangkan jika muanats disebut da'iyah. Jadi yang dimaksud dengan da'i ialah orang yang mengajak orang lain, baik secara lngsung maupun tidak langsung, bisa juga melalui lisan, tulisan maupun perbuatan untuk mengamalkaan ajaran-ajaran islam atau menyebarluaskan ajaran islam,yang bertujuan untuk selalu kejalan yang diridhoiNya. $^{2}$

Diantara modal kesuksesan da'i ialah: Sabar; Mengetahui psikologi dakwah;Memiliki kemampuan dalam ilmu (khususnya dalam agama); Memiliki akhlak yang baik; Memiliki persiapan materi yang cukup.

Sebelum menjadi seorang da'i yang diharapkan oleh masyarakat.seharusnya seorang Da'i harus mempunyai cirri khas kpribadian yang dipandang positif khususnya dari ajaran islam dan orang lain.kemungkinan Sifat-sifat seorang Da'i itu memang sangat banyak terkadang kita jarang sekali bisa membedakannya. Jadi paling tidak mereka mempunyai peganggan untuk menjadi seorang Da'i yakni Al-Qur'an dan Sunah. Bisa jadi tingkah laku seorang nabi bisa menjadi panutan untuk kita yang khususnya menjadi seorang Da'i. ${ }^{3}$

${ }^{1}$ Farijamakmun, Dakwah Pembangunan, (Lampung: Pusikamlah, 2009), h. 12

2 Enjang dan Aliyudin, 2009: h. 73-74

${ }^{3}$ Lalu muchsin Effendi dan Faizah, Psikologi Dakwah, (Jakarta: Kencana, 2006), h. 90 
Kepribadian yang dimiliki oleh seorang da'i menjadi unsure penting ketika melakukan dakwah, karena hakikatnya manusia itu sendiri menjadi yang menentukan dan unsur terpenting untuk sukses atau tidaknya seorang pendakwah. Ketika pendakwah itu punya kepribadian yang baik insayyaallah dakwah yang disampaikan untukn orang lain akan terjadi feedback, dan sebaliknya jika diri seorang pendakwah itu sendiri enggak punya daya tarik bagaimana untuk orang lain, bisa jadi usahanya menjadi seorang pendakwah akan gagal.

Perilaku seringkali merupakan pilihan individu sebagai hal yang layak dilakukan berdasarkan caranya mendefinisikan situasi yang ada. Definisi yang mereka berikan kepada orang lain, situasi, objek dan bahkan diri mereka sendirilah yang menentukan perilaku mereka. Jadi individulah yang dipandang aktif untuk mengatur dan menentukan perilaku serta lingkungannya sendiri. Sementara inti dari individu adalah kesadaran (consciousness). Dengan demikian, apa yang terjadi dengan masyarakat bangsa Indonesia pada hakekatnya merupakan cermin perilaku dan akumulasi tingkat kesadaran individu-individu warga negaranya. Oleh karena itu dalam perspektif ini, jika ingin mengubah kondisi bangsa Indonesia, maka kita harus memulainya dengan mengubah individuindividu warga negaranya.

Tema perubahan atau transformasi diri merupakan tema yang menarik perhatian, baik kalangan ilmuan sosial maupun agamawan. Dalam kajian ilmu sosial, transformasi diri banyak dibahas dalam psikologi, sosiologi dan ilmu komunikasi terutama dalam perspektif teori interaksionisme simbolik. Dalam kajian agama, permasalahan transformasi diri menemukan relevansi dan signifikansinya dalam ilmu dakwah. Bukankah transformasi merupakan makna luas dari dakwah Islam. Bukankah tujuan dakwah Islam adalah mengubah kondisi mad'u dari kondisi semula menuju kondisi yang lebih baik? Tulisan singkat ini mencoba menggali bagaimana transformasi diri ditinjau dalam perspektif dakwah dan komunikasi. 


\section{B. Pembahasan}

\section{Konsep diri}

a. Pengertian Konsep Diri

Konsep diri merupakan pemahama sikap individu terhadap diri sendiri sehingga mengakibatkan interaksi dua orang atau lebih. Konsep diri adalah faktor yang melakukan komunikasi dengan orang lain. Konsep diri merupakan pandangan dan sikap individu terhadap diri sendiri, karakteristik dan individual dan motivasi diri. Pandangan diri tidak hanya meliputi kekuatan-kekuatan individual tetapi juga kelemahan bahkan juga kegagalan dirinya. Konsep diri ini bersifat psikologis, sosial dan fisik. Menurut William D Broks dalam jalaludin rakhmat, kebanyakan para ahli setuju tentang konsep diri bahwa konsep diri secara harfiah dapat didefinisikan sebagai keseluruhan yang stabil sepajang kepribadian individu. Konsep diri dapat berkembang secara berkelanjutan meskipun sangat sulit untuk dapat membedakan antara perkembangan dan perubahan terhadap konsep diri.

Dengan adanya perkembangan serta perubahan tersebut dapat diterima konsep diri berkembang dan berubah seiringnya waktu dimasa anak-anak dan kecenderungan perkembangan yang berasal dari citra konsep diri baik secara positif maupun negative. Selanjutnya konsep diri terbentuk melalui adanya interaksi individu dengan lingkungan khususnya dilingkungan dari orang-orang yang signifikasi (orang tua). pada masa remaja memiliki sensitifitas sosial disertai kemampuan kognisi serta kemampuan dan preseptualnya menjadi lebih matang sehingga konsep diri menjadi lebih berbeda dan lebih lengkap.

\section{Transformasi Diri Sebagai Tujuan Dakwah}

Secara etimologi, dakwah terambil dari kata دعا بدعو دعوة yang secara memiliki kesamaan makna dengan kata al-nida' yang berarti menyeru atau me-manggil. Di dalam al-Qur'an, kata dakwah dan derivasinya terulang sebanyak 215 kali. ${ }^{4}$ Ketika menjelaskan istilah tersebut, pakar bahasa Ibnu Manzur menyebutkan beberapa arti yang terkandung seperti: meminta pertolongan, menghambakan diri, memanjatkan doa, persaksian

${ }^{4}$ Muhammad Fuad Abd al-Baqi, Mu'jam Mufahras li Alfaz alQur'an al-Karim (Beirut: Dar al-Fikr 2000), h. 330-3 
Islam dan memanggil atau mengundang (al-nida'). ${ }^{5}$ Islam disebut agama dakwah (din al-da'wah) karena ia mengajak orang agar berkenan mengikuti seruannya.

Adapun secara terminologis terdapat beberapa pengertian dakwah yang tidak seragam yang dikemukakan oleh para ulama. Syekh Ali Mahfudz misal-nya, mengartikan dakwah dengan memotivasi manusia kepada kebaikan dan petunjuk Allah SWT, serta mengajak untuk melakukan kebiasaan-kebiasaan yang dipandang terpuji dan mencegah mereka dari melakukan kebiasaan-kebiasaan yang dipandang tidak pantas oleh akal maupun syara'. ${ }^{6}$ Senada dengan itu, Ilyas Ismail, seraya mengutip dari Azizi Ibn Farhan al-Anzi, men-jelaskan bahwa dakwah juga dapat diartikan sebagai suatu aktivitas untuk memotivasi orang lain dengan basirah supaya menempuh jalan yang diridai Allah SWT. Basirah maksudnya pengetahuan yang mendalam dengan tujuan agar motivasi ini tepat sasaran. Dakwah Islam dengan basirah maknanya berarti dakwah yang disebarluaskan dengan cara damai dan bukan dengan kekerasan, serta mengutamakan aspek kogniti (kesadaran intelektual) dan afektif (kesa-daran emosional).

Sayyid Quthub mendefinisikan dakwah sebagai usaha untuk mewujudkan sistem Islam dalam kehidupan nyata, mulai dalam tatanan yang paling kecil, seperti individu, keluarga, hingga tatanan yang lebih besar seperti Negara atau ummah dengan tujuan mencapai kebahagiaan di dunia dan akhirat. Untuk me-wujudkan tujuan tersebut, menurut Quraish Shihab, diperlukan keinsafan atau kesadaran masyarakat untuk melakukan perubahan diri dari keadaan yang kurang baik menjadi lebih baik. Amrullah Ahmad mendefinisikan dakwah sebagai ikhtiar mengajak manusia masuk ke jalan Allah (sistem Islam) sehingga Islam dapat dilaksanakan dalam kehidupan pribadi(syakhsiyyah), keluarga (usroh), kelompok (jama'ah) sehingga tercipta khairul ummah. Dalam realisasinya, usaha mengajak itu dengan melibatkan unsur-unsur penyeru, pesan, media, metode, yang diseru, dan tujuan. Sementara itu, dalam pengertian yang

${ }^{5}$ Muhammad Mukarram Ibn Manzur al-Afriki al-Misri, Lisa>n al 'Arab (Beirut: Dar al Shadir, tt), XIV: 285

${ }^{6}$ M. Ali Mahfudz, Hidayah al-Mursyidin Ila< Turuq al A'zi wa alKhitabah (Beirut: Dar al-Ma'rifah, tt.), h. 17 
luas, menurut al-Bahiy, dakwah Islam pada hakikatnya adalah mengubah suatu situasi ke situasi yang lebih baik, sesuai ajaran Islam.

Dengan demikian, dapat dijelaskan bahwa dalam dakwah terdapat dua dimensi besar: Pertama, mencakup penyampaian pesan kebenaran, yaitu dimensi "kerisalahan" (bi ahsan al-qawl). Dimensi kerisalahan dakwah mencoba menumbuhkan kesadaran diri (individu/masyarakat) tentang kebenaran nilai dan pandangan hidup secara Islami, sehingga terjadi proses internalisasi nilai-nilai Islam sebagai nilai hidupnya. Dengan kata lain dakwah kerisalahan dalam prakteknya merupakan proses mengkomunikasikan dan menginternalisasikan nilai-nilai Islam. Kedua, mencakup pengaplikasian nilai kebenaran yang merupakan "kerahmatan" (bi ahsan al-'amal). Dakwah kerahmatan ini merupakan upaya mengaktualisasikan Islam sebagai rahmat (jalan hidup yang menyejah-terakan, membahagiakan, dan sebagainya) dalam kehidupan umat manusia. Dengan begitu, kalau dalam dimensi kerisalahan dakwah lebih cocok sebagai "pengenalan Islam" dan "penanaman kesadaran", sedangkan dalam dimensi kerahmatan, dakwah merupakan upaya mewujudkan Islam dalam kehidupan

\section{Konsep Diri dan Transformasi}

Pembahasan penting dari teori diri Mead adalah tentang konsep diri. Konsep diri adalah pandangan kita mengenai siapa diri kita, dan itu hanya bisa kita peroleh lewat informasi yang diberikan oleh orang lain terhadap diri kita. Mead mengatakan bahwa setiap manusia mengembangkan konsep dirinya melalui interaksi dengan orang lain dalam masyarakat-dan itu dilakukan lewat komunikasi. Dalam berkomunikasi, kita tidak hanya menanggapi orang lain, kita juga mempersepsi diri kita. Sebagai manusia, kita menjadi subjek dan objek sekaligus. Menurut Charles H. Cooley, kita melakukannya dengan membayang-kan diri kita sebagai orang lain; dalam diri kita. Cooley menyebutnya dengan the looking glass-self (diri cermin), seakan-akan kita menaruh cermin di depan kita. Dengan mmengamati diri kita, kita akan sampai pada gambaran dan penilaian diri kita, dan itulah konsep diri. 
Dengan teori the looking-glass self, Cooley berpendapat bahwa konsep diri individu secara signifikan ditentukan oleh apa yang ia pikirkan tentang pikiran orang lain mengenai dirinya. Jadi menekankan pentingnya respon orang lain yang ditafsirkan secara subjektif sebagai sumber primer data mengenai diri. Ringkasnya, apa yang diinternalisasikan sebagai milik individu berasal dari informasi yang ia terima dari orang lain. Suatu gagasan diri seperti ini tampak-nya memiliki 3 unsur, yaitu: imajinasi penampilan kita bagi orang lain, imajinasi penilainnya atas penampilan tersebut, dan sejenis perasaan-diri ( self-feeling), seperti kebanggaan atau malu.

William D. Brooks, sebagaimana dikutip Jalaluddin Rakhmat, mendefini-sikankonsep diri sebagai "those physical, social, and psychological perceptions of ourselves that we have derived from experiences and our interaction with others". Konsep diri adalah pandangan dan perasaan kita tentang diri kita, yang meliputi aspek fisik, psikologis dan sosial. Konsep diri bukan hanya sekedar gambaran deskriptif, tetapi juga penilaian tentang diri kita, mencakup apa yang kita pikirkan dan apa yang kita rasakan. Anita Taylor mendefinisikan konsep diri sebagai "all you think and feel about you, the entire complex of beliefs and attitudes you holds abaout yourself'.

Dengan demikian ada dua komponen konsep diri, yakni komponen kognitif dan komponen afektif. Bisa jadi komponen kognitif mengatakan: "Saya ini orang bodoh", tetapi komponen afektifnya bisa berkata:" Saya senang diri saya bodoh, ini lebih baik bagi saya", atau juga berkata: "Saya malu sekali karena saya menjadi orang bodoh". Komponen kognitif disebut citra-diri ( self image), sedangkan komponen afektif disebut harga-diri (self esteem). meremehkan apa pun dan siapa. Keempat, ia cenderung merasa tidak disenangi orang lain. Ia merasa tidak diperhatikan, sehingga ia beraeaksi kepada orang lain sebagai musuh. Ia tidak pernah mempersalahkan dirinya, tetapi menganggap dirinya sebagai korban. Kelima, ia bersikap pesimis terhadap kompetisi seperti terungkap dalam keengganannya untuk bersaing dengan orang lain dalam membuat prestasi.

Sebaliknya, orang yang memiliki konsep diri positif ditandai dengan bebe-rapa hal:

a. Ia yakin akan memampuannya mengatasi masalah; 
b. Ia merasa setara dengan orang lain;

c. Ia menerima pujian tanpa rasa malu;

d. Ia menyadari bahwa setiap orang memiliki berbagai perasaan, keinginan dan perilaku yang tidak seluruhnya disetujui masyarakat;

e. Ia mampu memperbaiki dirinya karena ia sanggup mengungkapkan aspek-aspek kepribadian yang tidak disenanginya dan berusaha mengubahnya. ${ }^{7}$

Mead menunjukkan bahwa perkembangan diri bergantung pada komu-nikasi dengan orang lain, terutama sejumlah kecil orang penting (significant others) yang membentuk atau mempengaruhi diri sebagaimana orang-orang tersebut dipengaruhi kehadiran diri tersebut. Komunikasi juga berperan penting dalam perkembangan masyarakat. Sebagaimana dikemukakan oleh Dewey: "Masyarakat eksis melalui komunikasi, perspektif yang sama-budaya yang sama-muncul melalui partisipasi dalam saluran komunikasi yang sama. Melalui partisipasi sosiallah perspektif bersama dalam kelompok diinter-nalisasikan dan berbagai pandangan muncul melalui kontak dan asosiasi yang sama." Dengan demikian, hanya orang yang memiliki konsep diri positiflah yang diharapkan terjadi transformasi dan perubahan dalam dirinya menuju kondisi yang lebih baik.

\section{E. Gejala-gejala Yang Muncul Dalam Diri Manusia}

a) Depresi

Depresi merupakan gangguan psikologi yang paling umum ditemui dan dirasakan oleh manusia yang ditandai oleh kondisi emosi, sedih, dan muram dengan gejala-gejala kognitif, fisik, dan interpersonal. Akan tetapi depresi merupakan gejala yang wajar pada diri manusia sebagai respon normal terhadap pengalaman hidup negatif, seperti pengalaman hidup menyedihkan, kehilangan anggota keluarga, dan benda berharga atau status sosial. Dengan demikian, depresi dapat dipandang sebagai suatu kontinum yang bergerak dari depresi normal sampai depresi klinis.

7 Jalaluddin Rakhmat, Psikologi Komunikasi (Bandung: Remaja Rosdakarya, 1998), h. 99 
Gejala gejala depresi normal seperti sedih, marah, perasaan tidak semangat, merasa tanpa harapan, menyerah dan lain-lain biasanya tidak berlangsung lama yaitu hanya pada saat berlangsunya kekecewaan saja. Ketika semua masalah dan kecewa nya sudah mulai berangsur apalagi ketika seorang individu berhasil mengatasi gejala-gejala tersebut, gejala depresi tersebut akan hilang dengan sendirinya. Depresi normal biasanya dilihat sebagai pengalaman yang adaptif. Depresi menjadi maladaptif dan abnormal bila hadir dalam intensitas yang tinggi dan berlarut larut yang akan mengakibatkan kesedihan yang mendalam, tidak ada semangat hidup, kehilangan gairah terhadap halhal yang menyenangkan atau yang dulu diminati.

Oleh karna itu kita harus meningkatkan kualitas pada diri kita agar dapat lebih dewasa dan berfikir positif ketik menghadapi permasalahan-permasalahan dalam hidup bagaimanapun menyedihkanya, agar kita terhindar dari rasa putus asa dan depresi selainitu harga diri juga sangat penting karna harga diri merupakan salah satu komponen yang lebih spesifik dari konsep diri, yang melibatkan unsur evaluasi atau penilaian terhadap diri. Selain itu harga diri juga merupakan aspek yang sangat penting dalam berfungsinya manusia, karena manusia memang sangat memperhatikan berbagaai hal tentang diri, termasuk siap dirinya, seberapa positif dan negatif seorang individu memandang dirinya, bagaimana citra yang ditampilkan pada orang lain, dll. Sehingga harga diri merupakan hal yang sangat penting yang harus kita miliki.

b) Perfectionisme

Perfectionisme dapat menjadi sifat yang adaptif dan mendorong seorang individu untuk mencapai prestasi tinggi. Hamachek membagi perfectionisme menjadi dua macam: yang normal dan yang neurotik. Menurut Hamachek, perfectionis yang normal dapat menetapkan standar pencapaian mereka dalam batas-batas keterbatasan dan kekuatan mereka.Dengan demikian, kesuksesan lebih mungkin dicapai dan raih oleh seseorang.

Perfectionist normal mendapatkan kepuasan dan kemikmatan mendalam dari upaya keras dalam melakukan 
sesuatu. Sebaliknya perfectionis yang neorotik menetapkan standar pencapaian yang lebih tinggi daripada yang biasanya dapat dicapai. Mereka sulit merasa puas karena mereka jarang berhasil melakukan sesuatu sebaik yang mereka inginkan.

Untuk mengukur aspek perfectionisme diperlukan beberapa butir skala yaitu: Ketakutan yang berlebih terhadap kesalahan yang dilakukan, Standart personal pada diri sendiri yang tinggi,Persepsi bahwa orangtua punya harapan yang tinggi terhadap diri, Persepsi bahwa orangtua amat kritis terhadap diri, Keraguan tentang kualitas tindakan yang dilakukan.

c) Stres

\section{Pengertian Stres}

Stres merupakan salah satu gejala psikologis yang dialami oleh seseorang yang mengalami tuntutan emosi berlebihan serta faktor-faktor yang membuatnya sulit memfungsikan secara efektif semua wilayah kehidupan. Keadaan ini dapat mengakibatkan munculnya banyak gejala seperti depresi, gelisah, rasa was-was, tidak peraya diri, minder, selalu menyendiri, mudah marah, impitensi, kualitas kerja yang rendah, merasa hidup sendiri dan lain sebagainya.

Stres merupakan reaksi fisik terhadap permasalahan kehidupan yang dialaminya dan apabila fungsi organ tubuh sampai terganggu maka dinamakan distres. Faktor yang menyebabkan terjadinya stres sangatlah banyak. Seringkali seseorang megalami hal seperti ini karna sedang mengalami permasaahan dalam hidupnya, rumah tangganya maupun pendidikannya. Lain halnya dengan depresi. Seseorang seringkali merasa banyak beban, stres dan lainnya yang menyebabkan hingga munculnya depresi. Depresi merupakan reaksi kejiwaan terhadap stresor yang dialaminnya. Namun, dalam banyak hal, orang yang mengalami stres dan depresi ini masih bisa dikendalikan. Mereka mencari cara untuk masa pemulihan dari apa yang dialaminya. Biasanya ha ini juga disesuaikan dengan situasi dan kondisinya. Orang-orang yang mengalami hal ini butuh 
support dari pihak lain untuk saling menguatkan, memberikan motivasi dan lain sebagainya.

2. Aspek-aspek Stres

Ada dua aspek yang ditimbulkan dari stres antara lain: Aspek fisik, yang berdampak pada menurunnya kondisi seseorang pada saat stres hingga orang tersebut mengalai sakit pada organ tubuhnya, seperti sakit kepala, gangguan pencernaan, sakit perut dll yang bisa memengaruhi organ tubuhnya. Aspek psikologi, hal ini erdiri dari gejala-gejala psikologis seperti gejala emosi dan gejala tingkah laku. Aspek psikologi ini dapat menurunkan daya produktifitasnya, sehingga berdampak negatif seperti menurunnya daya ingat, merasa sedih dan sering menyendiri, serta menunda pekerjaan karna memang sudah tidak fokus lagi.

Berdasarkan teori yang dijelaskan di atas, maka dapat disimpulkan bahwa aspek-aspek tersebut terdiri atas aspek fisik dan aspek psikologis. Kedua aspek inilah yang dijadika sebagai standar akademik.

\section{Faktor-faktor Stres}

Setiap teori yang bebeda memiliki konsepsi atau sudut pandang yang berbeda dalam melihat penyebab dari berbagai gangguan fisik yang berkaitan dengan stres. Berikut ini akan dijelaskan terkait beberapa sudut pandang tersebut:

a) Sudut pandang psikodinamik

Dalam sudut pandang psikodinamik ini mendasarkan bahwa gangguan tersebut muncul sebagai akibat dari emosi yang di refresh atau yang ditimbulkan.

Hal-hal yang di refresh (ditimbulkan) ini akan menentukan organ tubuh mana yang terkena penyakit. Sebagai contoh, apabila seseorang merefresh kemarahan, maka kondsi tersebut dapat memunculkan esensial hiperensional (emosi yang berlebihan). 
b) Sudut pandang biologis

Salah satu sudut pandang biologis disebut dengan somatic weakness model. Dalam sudut pandang ini stres yang ditimbulkan ini akibat lemahnya organ tubuh individu. Dalam kondisi ini dapat mengakibatkan kerentanan pada tubuh serta organ tubuh lainnya menjadi lebih lemah daripada organ lainnya hingga akhirnya mengalami kerusakan ketika seseorang dalam kondisi tertekan dan tidak fit akibat stres tersebut.

c) Sudut pandang kognitif dan perilaku

Sudut pandang kognitif ini menekankan pada presepsi dan reaksi yang dialami seseorang terhadap ancaman (fator-faktor dari luar). Seluruh presepsi individu ini dapat mengakibatkan stres. Munculnya emosi yang negatif seperti perasaan cemas, kecewa, marah, sedih dan sebagainya dapat membuat sistem ini tidak berjalan dengan berjalan lancar dan pada suatu titik tertentu akhirnya memunculkan peyakit. Berdasarkan penelitian diketahui bahwa bagaimana seseorang mengatasi kemarahannya ternyata berhubungan dengan penyakitin tekanan darah tinggi (fausiyah dan widuri, 2005).

Stres bersumber dari frustasi dan konflik yag dialami individu dapat berasal dari berbagai bidang kehidupan manusia. Dalam hal hambatan, ada beberapa macam hambatan yang biasanya dihadapi oleh individu seperti:

1. Hambatan fisik: hambatan ini berupa gejala-gejala seperti kemiskinan yang dialami seseorang (faktor ekonomi), kekurangan gizi, pendidikan, bencana alam dan sebagainya.

2. Hambatan sosial: kondisi perekonomian yang tidak bagus, persaingan hidup yang keras, perubahan tidak pasti dalam berbagai aspek kehidupan. Hal-hal sepperti ii yang mengakibatkan seseorang mengalami frustasi hingga akhirnya stres dan depresi.

3. Hambatan peribadi: keterbatasan-keterbatasan peribadi individu dalam bentuk cacat fisik, penampilan 
fisik yang kurang menarik, merasa tidak memiliki potensi, merasa minder dan lain sebagainya dapat memicu frustasi dan stres pada individu.

Konflik yang dialami seseorang seperti merasa selalu kurang, tidak bisa memenuhi kebutuhannya, adanya keingin yang belum tercapai hingga faktor-faktor sosial dan biologis lainnya pada akhirnya menyebabkan timbulnya stres. Yusuf (2004) faktor pemicu stres itu dapat diklasifikasikan ke dalam beberapa kelompok berikut:

1. Stres fisik/biologis, seperti: stres ini disebabkan karna faktor-faktor alami yang memang sudah menjadi kehendak Allah. Stres ini biasanya timbul akibar rasa kurang percaya diri karna tidak cantik, terlalu kecil, warna kulit yang gelap dan lain sebagainya. Stres inilah yang seringkali menggerogoti diri sendiri. Tidak bersyukur dengan apayang Allah berikan. Penyakit ini bisa disembuhkan dengan dinasehati, di motivasi dan lain-lain agar mau menerima apa yang telah Allah berikan.

2. Stres Psikologis, seperti adanya sifat negative thinking atau berburuk sangka, frustasi (kekecewaan karena gagal memperoleh sesuatu yang diinginkan), hasud (iri hati atau dendam), sikap permusuhan, perasaan cemburu, konflik pribadi, dan keinginan yang diluar kemampuan.

3. Stres Sosial, hal ini biasanya disebabkan karna tidak harmonisnya hubungan rumah tangga, selalu merasa kurang, faktor ekonomi, serta pendidikan yang tidak dapat dipenuhi.

Ada dua maccam stres yang dihadapi oleh individu, yaitu:

1. Stres yang ego-envolved: stres ini dikategorikan dalam stres kecil-kecilan. Stres ini tidak memengaruhi organ tubuh.

2. Stres yang ego-involed: stres ini dikategorikan dengan stres berat akibat faktor-faktor yang dapat mengancam integritas serta produktifitas seseorang. Hal ini 
telah dijelaskan diatas, karna adanya beberapa faktor penyebabnya. Kedaan stres inilah yang memerlukan penanganan yang benar dan tepat dengan melakukan reaksi penyesuaian agar tidak hancur akibat stres tersebut.

Berdasarkan uraian diatas, dapat disimpulkan bahwa stres ini dipengaruhi beberapa faktor, baik fisik/biologis, faktor psikologis, dan faktor sosial. Adanya pemicu-pemicu yang timbul ini dapat menurunkan daya kreatifitas seseorang. Dalam hal ini diperlukan penangan yang benar dan tepat agar dapat memulihkan stres yang terjadi. Dan hal yang palimh penting yaitu dengan selalu berbaik sangka (khusnudzon) terhadap Allah dan senantiasa mendekatkan diri kepada Allah agar Allah kuatkan hati, fikiran serta lainnya.

\section{F. Konsep Diri Seorang Da'i}

a) Da'i Pondok Pesantren

Pondok pesantren yang melembaga dimasyarakat, terutama yang diperdesaan adalah salah satu lembaga pendidikan islam yang tertua di indonesia awal mula kehadiran pondok pesantren bersifat budaya untuk mendalami ilmu agama sebagai tujuan hidup (tafaqqufi aldin) yaitu menegaskan pentingnya adat dalam bermasyarakat. mastubuh (1994 mengatakan munculnya pondok pesantren di indonesia diperkirakan masuk pada tahun 300400 taun silam dan terjangkau setengah diseluruh masyarakat islam (1940-1985) dipulau jawa. Pondok pesantren adalah lembaga pendidikan yang beraneka macam tidakhanya keberadaanya yang sudah sangat lama, tetapi budaya, dan jaringan yang diterapkan oleh pondok pesantren itu karna keunikanya C. Grertz dan Abdulrohman Wahid menyebutkan bahwa sekultur masyarakat yang ada diindonesia terutama dipulau jawa dan zaman penjajahan pesantren merupakan tujuan utama perjuangan nasioanalis pribumi indonesia.

Pondok pesantren dalam kiprahnya sangat dirasakan oleh masyarakat setempatnnya yang menjadi contohnya ialah, selain pembentukan pemimpin-pemimpin ulama dan 
membangun keilmuan adalah merupakan gerakan pernyataan yang tidak setuju yang terhadap peerintah kolonel pernyataan yang tidak setuju terseju diplopori oleh para santri celegon banten 1888 dan kartodijo 1983 pejuang jihat aceh 1973 gerakan yang diplopori ahmad ripangi kalisalak 1786-1875 yang merupakan fakta yang tidak bisa dicegah bahwa pondok pesantren itu memiliki peran yang cukup dan andil dalam perjuanagn sejarah islam.

Setelah kemerdekaan indonesia semenjak berpindah keorde baru dan ketika eknomi bertumbuh sangat baik tajam, pelajaran dipondok pesantren lebih tersusun rapih dan pembelajaranya menjadi lebih nyaman contohnya pembelajaran genda yaitu, kurikulum kementrian nasional agama karena dianggap kurikulum tersebelum mengakomodir semangat isi pesantren proses pembangunan penididikan pesntren adalah penanggung jawab pesantren itu juga. pesantren itu didukung oleh pemerintah sebagai awal pendirian manusia selayaknya tingkatan pembangunan peran serta dalam pondok pesantren awal pembangunan di era otonomi daerah langkah yang strategis dalam upaya mencapai tujuan pendirian nasional terutama sektor pendidikan terlebihnya lagi dalam kondisi bangsa yang tengah mengalami krisis moral atau adap. Pondok pesantren lebih ternilai dan bermakna selembaga pendidikan yaitu membentuk dan mengembangkan nilai-nilai adat menjadi pelapor atau inspirator kebangkitan negara.

Sehiggga penillan yang tidak menjadi kosong tapi lebih bernilai dan berarti dengan keinginan yang luhur yang membina dan mengembangkan msyarakat dengan mandirinya, pondok pesantren secara terus menerus melakukan pembangunan dan penguatan diri sendiri walaupun terlihat tidak berjalan dengan lancar, iri senciri yang didukung keimana yang kuat pondok pesantren bisa membangun pendidikan dan eksitensi dirinya yang berkesimbunagan dalam hal ini penulis akan membahas sejarah pesantren dan pembangunanya, pengembanganya, pesantren antara tujuan dan tantangan serta fungsi dan tujuan pendidikan pondok pesantren yang akan datang. 
b) Komunikasi Dakwah Da'i Akademisi

Dakwah adalah menyeru atau mengajak seseorang dalam menjalankan amar ma'ruf nahi munkar. Dalam berdakwah pun harus memiliki seni dalam komunikasinya agar apa yang disampaikan dan apa yang menjadi tujuannya dapat tersampaikam dengan jelas. Dalam hal ini proses komunikasi yang baik sangat diperlukan untuk keberhasilan dakwah tersebut. Dengan adanya proses komunikasi yang baik seperti memahami terlebih dahulu latar belakang dari lawan bicara dan lain sebagainya akan menimbulkan kedekatan emosional tersendiri.

Dakwah sendiri memiliki tujuan agar seseorang dapat berbuat kebaikan, menajlaankan apa yang sudah menjadi kewajibannya serta mengamalkan apa yang diperoleh dan menjauhi segala larangan Allah. Dakwah ini ingin menjadikan seseorang hidup tenram, aman, nyaman dibawah naungan allah. Senantiasa mendekatkan diri kepada Allah.

Untuk mencapai tujuan tersebut diperlukan komunikasi yang baik. Baik komunikasi terhadap Allah (Habliuminallah) atau hubungan baik terhadap manusia (Habluminannas). Proses yang mendasar dalam komunikasi dakwah adalah penggunaan bersama atau dengan kata lain ada yang memberi informasi (mengirim) dan ada yang menerima informasi. Penggunaan bersama tidak harus yang memberi dan yang menerima harus saling berhadapan secara langsung tetapi bisa melalui media lain, seperti tulisan, isyarat, maupun yang berupa kode-kode tertentu yang bisa dipahami, terkhusus di zaman saat ini yang sangat memudahkan untuk berkomunikasi serta berdakwah melalui sosial media dan iptek yang ada. ${ }^{8}$

Komunikasi dakwah merupakan bagian dari tindakan memengaruhi yang dapat menggunakan cara persuasif. Maksud komunikasi persuasif dalam kerangka dakwah adalah komunikasi yang senantiasa berorientasi pada segisegi psikologis mad'u dalam rangka membangkitkan kesadaran mereka untuk menerima dan melaksanakan ajaran islam. Dari kegiatan komunikasi persuasif dapat

${ }^{8}$ Jurnal Al-Khitabah, Vol.II, No.1, Desember 2015: 71-82 
menimbulkan suatu kesadaran, kerelaan, serta perasaan senang sebelum dan sesudah menerima pesan dakwah atau proses komunikasi.

\section{G. Kesimpulan}

Berdasarkan dari pembahasan di atas, dapat disimpulkan bahwa seseorang yang aan melakukan dakwah, hendaknya memahami terlebih dahulu terkait psikologi komunikasi dan psikologi dakwah. Karena, dalam berdakwah kedua psikologi ini sangat dibutuhkan terutama dalam mencapai tujuan serta visi misi berdakwah. Psikologi komunikasi sangat penting digunakan karena kita harus memahami dan mengerti bagaimana tata cara berkomunikasi yang baik, seni berbicara yang baik sehingga bisa menyesuaikan dengan bahasa kaumnya. Tak hanya itu saja, dalam berdakwah psikologi juga sangat penting, dengan ini kita bisa mengerti latar belakang mad'u yang akan kita dakwahi dengan demikian akan memiliki kedekatan emosional tersendiri.

Dalam psikologi dakwah juga sangat dibutuhkan demi kelancaran dalam berdakwah. Karna dengan ini, seorang Da'i bisa mengemas semenarik mungin apa yang akan disampaikan agar tidak membosankan. Memiliki strategi dalam berdakwah yang disesuaikan dengan perkembangan zaman.

Dalam diri manusia juga terdapat gejala-gejala yang sering muncul karna beberapa faktor, yaitu faktor biologis/fisik, faktor psikologis dan faktor sosial. Kita juga haru mengerti serta memahami terkait hal tersebut. Agar bisa memberikan penanganan yang baik serta sesuai dengan kebutuhan yang sedang dialaminya.

Konsep diri ini sangat penting dalam suatu keberhasilan, terutama berdakwah. Mengemas diri dengan baik, memahami bagaimana keadaan mad'u serta senantiasa belajar dan menjaga hubungannya dengan Allah. 


\section{Daftar Pustaka}

Alwisol 2006. Psikologi Kepribadian, Malang. UMM press.

Aminudin, Sanwar, 2009, Ilmu Dakwah, Semarang: Suatu Pengantar Study.

Arifin M, 2003 Psikologi Dakwah Suatu Pengantar Studi, Jakarta: Bumi Aksara.

Ariyono Suyono, 1982 Kamus Antropologi (Jakarta: Akademik Persindo)

Asmuni Syukir, 1983 Dasar-dasar Strategi Dakwah Islam, (Surabaya: Al-Ikhlas)

Bintarto. 1982. Interaksi desa kota dan permasalahanya. Jakarta.

Faizah dan Muchsin Effendi,2006, Psikologi dakwah, Jakarta: Kencana.

Farijamakmun, Dakwah Pembangunan, (Lampung: Pusikamlah, 2009)

H. M. Alfandi,, 2009. Strategi Dakwah Majilis Ulama Indonesia (MUI) di Tengah Arus Globalisasi dan Informasi, (Semarang: Lembaga Penelitian dan Pengabdian Masyarakat IAIN Walisongo)

Hasan Langgulung, 1982 Teori-Teori Kesehatan Mental (Jakarta: Alhusna)

Jalaluddin Rakhmat, Psikologi Komunikasi (Bandung: Remaja Rosdakarya, 1998)

Jurnal Al-Khitabah, Vol.II, No.1,Desember 2015

Lalu muchsin Effendi dan Faizah, psikologi Dakwah, (Jakarta: Kencana, 2006)

M. Ali Mahfudz, Hidayah al-Mursyidin Ila Turuq al A'zi wa al-Khitabah (Beirut: Dar al-Ma'rifah, tt.)

Muhammad Fuad Abd al-Baqi, Mu'jam Mufahras li Alfaz al-Qur'an alKarim (Beirut: Dar al-Fikr 2000)

Muhammad Mukarram Ibn Manzur al-Afriki al-Misri, Lisa>n al 'Arab (Beirut: Dar al Shadir, tt)

Muhammad Munir dan Wahyu Ilahi, 2006 Menejemen Dakwah, (Jakarta: Kencana) 
Pimay, Awaluddin, 2005 Paradikmah Dakwah Humanis: Strategi dan Metode Dakwah Prof KH Syaifudin Zuhri, Semarang: Rasail.

Rafiuddin dan Mannan Abdul Jalil, 1997 Prinsip dan Strategi Dakwah, Bandung: Pustaka Setia.

Samsul Munir Amin, 2008 Rekontruksi Pemikiran Dakwah Islam, (Jakarta: Amzah).

Soedjono, 1982 soekanto. Pengantar sosiologi. Jakarta. Soerjono Soerkapto, 1982 Kamus Sosiologi (Jakarta: Rajawali). 
226 | Jurnal Bimbingan Penyuluhan Islam, Vol. 01, No. 02 Juli-Desember 2019 